\title{
НАУКОВІ ПІДХОДИ ДО ДОСЛІДЖЕННЯ ПРОБЛЕМИ РОЗВИТКУ ГРОМАДСЬКОЇ ДІЯЛЬНОСТІ СТУДЕНТСЬКОЇ МОЛОДІ В ЗАКЛАДАХ ВИЩОЇ ОСВІТИ УКРАЇНИ ХХ СТ.
}

\author{
(C) Кін О.М., 2020 \\ https://orcid.org/0000-0002-1935-6483 \\ http://doi.org/10.34142/2312-2471.2020.63.08
}

У статті представлені різні наукові підходи, щуо дозволяють трунтовно дослідити та проаналізувати проблему розвитку громадської діяльності студентської молоді вищих навчальних закладів Украӥни XX століття. Актуальність проблеми зумовлена суперечностями, зокрема: між необхідністю врахування впливу прочесів громадської діяльності студентів на формування особистості ци недостатністю дослідження національного молодіжного руху як інституту соџіалізащзї $і$ виховання молодого покоління. Метою статті є вивчення та аналіз різних наукових підходів до дослідження проблеми розвитку громадської діяльності студентськоӥ молоді вищих навчальних закладів України XX століття. Автором були використані такі методи дослідження: аналіз, узагальнення, систематизація історикопедагогічних, науково-методичних працьв учених з проблеми розвитку громадської діяльності студентської молоді. У статті показано, щуо для здійснення об'єктивного $і$ комплексного дослідження розвитку $i$ організації громадської діяльності студентів XX століття в Україні доцільно використовувати сукупність науково-методологічних підходів. Було доведено, щзо базовими для нашого дослідження стали такі підходи: системний, синергетичний, історіографічниц̆, культурологічний, хронологічний, історичний феноменологічний, аксіологічний, цивілізаційниц̆, парадигмальнопедагогічний. Автором представлено змістовну характеристику кожного 3 наукових підходів, визначено їхню сутність, особливості використання у науково-дослідній практиці. У статті простежено закономірності виникнення та розвитку кожного з підходів, встановлено їхнє місие і практичне значення у науковому полі досліджуваної проблеми. Було доведено, щуо система зазначених наукових підходів дозволить відобразити ияілісність досліджуваних процесів $i$ явищ, обгрунтувати закономірності розвитку $і$ становлення даної наукової проблеми, дати об'єктивну $і$ змістовну характеристику основним науковим категоріям дослідження, простежити тендениії $i$ закономірності розвитку громадської діяльності студентської молоді України ХХ століття.

Ключові слова: громадська діяльність, студенти, наукові підходи. 
Kin O.M.. Scientific Approaches to the Problem of Public Activity Development for Student Youth in Higher Educational Institutions in Ukraine in the $20^{\text {th }}$ Century

Different science approaches for research and analysis the development problem of social activity for student youth at Ukrainian universities in the twentieth century are represented in the article. The problem actuality is substantiated by contradictions, particularly between the necessity to consider the processes influence of social students' activity on personality formation and insufficient research of the national youth movement as an institution of socialization and education for the young generation. The purpose of the article is learning and analysis of the different science approaches to research the development problem of student youth social activity at Ukrainian universities in the twentieth century. The following research methods as analysis, generalization, systematization of historical and pedagogical, scientific and methodological works of scientists about the development of student youth social activities were used by the author in the article. In the article it is indicated that to carry out an objective and comprehensive study for the development and organization students' social activities at the twentieth century in Ukraine, it is advisable to use a set of scientific and methodological approaches. It was proved that the following approaches were basic for our research: systemic, synergetic, historiographical, culturological, chronological, historical phenomenological, axiological, civilizational, paradigmatic and pedagogical. The author presented a meaningful description of each scientific approach, defined its essence, features of use in a research practice. The article traced the patterns of origin and development for each approach, established the place and practical significance in the scientific field of the problem. It is proved that the system of these scientific approaches will reflect the integrity of the studied processes and phenomena, substantiate the patterns of development and formation of the scientific problem, give an objective and meaningful description of the main scientific categories of the research, trace trends and patterns of social activity for Ukrainian students in the twentieth century.

Key words: social activity, students, scientific approach

Постановка проблеми. На сучасному етапі інтенсивного розвитку всіх сфер соціального життя у країні, актуалізації цінності набутого культурноісторичного досвіду особливої уваги набувають питання розвитку громадянської активності молоді в історії національної вищої школи.

Аналіз останніх досліджень. Окремі аспекти проблеми організації громадської діяльності молоді були предметом спеціальної уваги різних фахівців. Так, історію розвитку громадської діяльності молодіжних об'єднань України розглядали I. Андрухін, І. Головенький, В. Міяковський, С.Черкасова, Н. Якушко.

Особливості молодіжного громадського руху в Україні вивчали В. Астахов, І. Бережний, М. Головатий, В. Головенько, О. Корнієвський, Р. Пальчевський, В.Прилуцький, Б. Савчук, І. Шумський та ін. 
Виділення невирішених раніше частин загальної проблеми. Однак питання становлення та розвитку громадської діяльності студентської молоді закладів вищої освіти України ХХ ст. та наукових підходів до їі вивчення не були предметом спеціального вивчення й системного аналізу.

Мета роботи - проаналізувати різні наукові підходи до дослідження проблеми розвитку громадської діяльності студентської молоді закладів вищої освіти України XX ст.

Методи дослідження: аналіз, узагальнення, систематизація історикопедагогічних, науково-методичних праць учених стосовно проблеми розвитку громадської діяльності студентської молоді.

Виклад основного матеріалу. Громадська діяльність студентської молоді вищих навчальних закладів України ХX ст. зумовлюється конкретними історичними умовами та політичними, соціальними, економічними чинниками розвитку суспільства означеного періоду. Для глибокого й змістовного дослідження вагоме значення мають підходи до вивчення процесу розвитку та становлення громадської діяльності студентської молоді, що дозволяють здійснити об'єктивний i комплексний аналіз теорії і практики організації громадської діяльності в означених хронологічних межах дослідження.

Під «методологічним підходом» Л. Шипіліна розуміє спосіб вивчення об'єкта, що ставить кордони його пізнання й визначає загальну стратегію дослідження [12, с. 29].

Базовими підходами є: системний, синергетичний, історіографічний, культурологічний, хронологічний, історичний феноменологічний, аксіологічний, цивілізаційний, парадигмально-педагогічний.

Поняття «системний підхід» стало використовуватися науковцями ще 3 30-х pp. ХХ ст. Системний підхід розглядали як спосіб наукового пізнання, що передбачає комплексне дослідження наукової проблеми, вивчення ऑiі як системного явища, яке об'єднує взаємопов'язану комбінацію окремих елементів 3 можливою подальшою модернізацією як усієї системи, так i ii складових спеціалістами різних галузей. 3 початку 90-х pp. XX ст. системний підхід набув статусу самостійного наукового напряму. Як складну систему стали розглядати педагогічний процес, соціальне i виховне середовище, особистість учня і вихованця.

Системний підхід було проаналізовано низкою вчених, зокрема: В. Андрущенко, Р. Атахановим, В. Загвязинським, С. Гончаренком, В. Краєвським, О. Крушельницькою, О. Сухомлинською, А. Уйомовою.

На думку вчених, системний підхід вимагає досліджувати певну проблему як цілісну, складну систему, елементи якої мають різноманітні зв'язки як між собою, так і з оточуючим середовищем. Система, як правило, є динамічною, розвиток якої визначається впливом певних чинників і умов.

Сутність системного підходу реалізується у чіткому визначенні всіх елементів системи, вивченні окремих елементів і частин, у нерозривній єдності 3 цілим, у послідовності процедур для побудови «складно-організованого об'єкта як системи», дослідженні інтегративних властивостей об'єкта як 
системи із зовнішніми й внутрішніми зв'язками, у цілісності системи відносно навколишнього середовища, виявленні і визначенні усього спектру зв'язків i представленні усіх зв’язків у вигляді стрункої, цілісної системи.

Цілісне бачення педагогічного процесу в окремих закладах вищої освіти та визначення тенденцій розвитку студентського громадського руху в системі вищої освіти України в цілому, дозволяє вивчити складну нелінійну систему педагогічних взаємин із здійсненням системного аналізу феномену студентської громадської діяльності в педагогічній теорії та практиці.

Поняття «синергетика» (від грецького бvvєрүí $\alpha$ - спільна дія) ввів до наукового обігу Г. Хакен, який вважав ii галуззю науки, що займається вивченням ефектів самоорганізації у фізичних системах або більш широкому класі систем. Новий ракурс, запропонований синергетикою для вивчення проблем саморозвитку, самоорганізації матеріальних систем, мав певні особливості: вивчалися практично всі існуючі об'єкти системи, увага концентрувалася на вивченні конкретних механізмів виникнення i вдосконалення самоорганізації, зазначалося, що ефекти впорядкування, які виникають в динамічних системах, зобов'язані своєю появою дії різних нелінійних процесів.

У своїх роботах «Що загального виявляється при дослідженні систем всілякого роду, природних i соціальних?», «Синергетика» [11] Г. Хаген обгрунтував основну ідею синергетики про виникнення стійких, самоорганізованих структур у великих системах, які взаємодіють між собою й впливають один на одного. Подальшого розвитку теорія синергетики знайшла в роботах О. Карпенко, В. Лутай, І. Предборської, В. Пріснякова.

Дослідниками було виділено принципи синергетичного підходу (відкритість, нелінійність, самоорганізація, стійкість - нестійкість), умови застосування (у контексті теорії самоорганізації, для дослідження суто відкритих систем), особливості, закони тощо, що дозволило представити синергетичний підхід як струнку теорію самоорганізації в складних відкритих системах.

Синергетичний підхід дозволив нам простежити проблему громадської діяльності студентської молоді в контексті складних соціально-політичних, економічних, ідеологічних процесів XX ст. й дослідити загальні тенденції іï розвитку; осмислити одночасне існування в історичній реальності багатьох форм громадської діяльності студентів, виявити їх взаємодію, взаємовплив i зробити висновок, що результатом цієї взаємодії є виникнення нових напрямів громадської діяльності.

Як відомо, історіографія - це спеціальна дисципліна, яка вивчає історію, розвиток історичної думки, розвиток історичних подій і процесів. Проблеми історіографії були предметом спеціальної уваги багатьох учених. Українська історіографія отримала значний поштовх у розвитку з поч. ХХ ст. Так, окремі аспекти проблеми розглядалися Д. Багалієм (розвиток науки та освіти); Д. Дорошенком (розвиток української історичної науки), М. Грушевським (історія української думки, національної самосвідомості народу) та ін. 
Дослідження С. Ананьїна, Г. Іваниці, О. Лотоцького, Я. Мамонтова, О. Музіченка, В. Науменка, С. Постернака, С. Русової, Я. Чепиги започаткували і дали розвиток вітчизняній педагогічній історіографії.

На сьогодні історіографія збагатилася грунтовними, змістовними

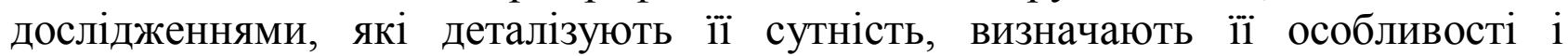
завдання, функції і методи. Так, С. Посохов [8] підкреслює «багатоликість» історіографії і розглядає іiі як наукознавчу, літературознавчу і культурологічну дисципліну.

Ю. Горбань [2] визначає переваги історіографічного підходу, який дозволяє виділити конкретні етапи дослідження, визначити основні ідеї теми дослідження, віднайти проблеми, що є близькими до досліджуваної теми, проте залишилися невирішеними і потребують уточнень і доповнень із залученням невідомих раніше фактів, висвітлити проблеми, які взагалі залишилися поза увагою попередніх дослідників й потребують опрацювання.

Таким чином, історіографічний підхід дозволяє розкрити стан розробленості проблеми та умови організації громадської діяльності студентської молоді в Україні досліджуваного періоду, ознайомитися 3 історіографічними джерелами та проаналізувати джерельну базу, обгрунтувати доцільність вибору теми дисертаційного дослідження, визначити його мету та завдання i, звичайно ж, новизну отриманих результатів.

Культурологічний підхід безпосередньо пов'язаний із поняттям «культурологія». Цей термін було застосовано ще в 1909 р. німецьким філософом і фізиком В. Освальдом для опису специфічних явищ, які складають культуру. Учений чітко визначив різницю між культурологією та соціологією й обгрунтував поняття «культури» як феномен суто людської діяльності.

Проте культурологічний підхід оформився в окремий i увійшов до широкої наукової практики лише наприкінці XX ст. завдяки розвитку ідей культурологічного спрямування в дослідженнях спеціалістів різних наук: Л. Виготського, О. Леонтьєва, О. Лурія (культурно-історична психологія), М. Бахтіна, І. Берлянд, В. Біблера (концепція діалогу культур).

На сьогодні культурологічний підхід активно застосовується науковцями у дослідженнях 3 різних дисциплін: філософії, соціології, культурології, психології та ін.

Особливої уваги заслуговують роботи, які розглядають використання культурологічного підходу в педагогічних дослідженнях. В. Гура, А. Погодіна, I. Балхарова, Є. Фортунатова, I. Колмолгорова обгрунтували основні концептуальні положення культурологічного підходу, загальні принципи організації освітнього процесу в контексті означеного підходу.

Так В. Гура підкреслював, що особистість, яка $\epsilon$ центром уваги дослідника, необхідно розглядати як суб'єкт культури, що обумовлює врахування іiї індивідуальності, активності, внутрішньої свободи, здібності до взаємодії з іншими особистостями. Навчальне середовище, на думку вченого, повинне відбудовуватися згідно з вимогами культурного середовища, яке в змозі допомогти особистості з самовизначенням [3, с. 11]. 
Продовжуючи означені ідеї, М. Бастун зазначає, що культурологічний підхід у педагогіці дозволить досліднику вибудувати та спеціально організувати культурне середовище для успішного і результативного процесу навчання та виховання [1, с. 172$]$.

Цікавими для нашої роботи є ідеї щодо значення культурологічного підходу для історико-педагогічних досліджень. Так, І. Шкабара підкреслює, що саме культурологічний підхід надає унікальну можливість вивчати та аналізувати історію розвитку окремих педагогічних ідей, теорій і процесів в контексті культурно-історичних особливостей певних періодів, дозволяє навіть уточнити саме поняття «парадигма освіти» [13, с. 42 ].

Таким чином, культурологічний підхід дозволяє розглядати громадську діяльність студентської молоді як важливий компонент реалізації завдань соціалізації, виховання, розвитку молоді в контексті моральних, духовних, соціальних вимог i потреб, що були визначені культурним стандартом суспільства. Культурологічний підхід дає змогу зосередити спеціальну увагу на місці особистості в системі культурних цінностей народу.

Культурологічний підхід дозволяє також розглянути витоки самої ідеї становлення громадянської активності і діяльності студентів через комплекс ідей, фактів, подій історико-культурного характеру.

Сутність і значення хронологічного підходу для історико-педагогічного дослідження були представлені в роботах Л. Березівської, Н. Гупана, В. Кушнір. Автори зазначають, що саме хронологічний підхід надає можливість систематизувати джерела, що досліджуються, представити їх у певній хронологічній послідовності, простежити, як змінювалися і розвивалися окремі сторони педагогічного процесу в різні історичні періоди, розробити обгрунтовану періодизацію.

Н. Богданець-Білоскаленко, М. Букач, Н. Клименюк, Т. Попова, О. Сухомлинська у своїх роботах обгрунтували сутність хронологічного підходу і визначили його значення для дослідження. Отже, хронологічний підхід спрямовано на вивчення історичного досвіду, визначення етапів становлення й розвитку об'єкта дослідження від моменту виникнення до часу вивчення проблеми науковцем.

Перевагами хронологічного підходу $\epsilon$ можливість істотно збагатити наукове дослідження інформацією щодо розвитку процесів та подій у хронологічній послідовності, підвищити рівень його достовірності; простежити й обгрунтувати послідовність та взаємозв'язок соціально-історичних та культурно-освітніх процесів; наявність широкого хронологічного фону для вивчення історико-педагогічної науки.

Хронологічний підхід у контексті проблеми, що вивчається, дає змогу простежити динаміку розвитку громадської діяльності студентів протягом XX століття завдяки аналізу хронологічних подій, суспільних процесів, соціальнополітичних, економічних та культурологічних явищ; у чіткій послідовності вивчити процес іiі становлення, розробити періодизацію означеного процесу в окреслений період, обгрунтувати етапи і провідні тенденції розвитку проблеми 
організації громадської діяльності студентів.

Сутність історичного підходу було розкрито і науково обгрунтовано в роботах А. Вовк, В. Кушнір, С. Кошкіної, О. Сухомлинської, І. Ящук та ін. На думку науковців визначальною ідеєю історичного підходу є особлива побудова вивчення педагогічних процесів, явищ і подій: від абстрактного до конкретного. Отже, історичний підхід поєднує логічні й історичні методи пізнання у процесі дослідження.

Як зазначає В. Кушнір, основним принципом історичного підходу $\epsilon$ фундаментальний для історико-педагогічного дослідження принцип історизму, який висвітлює події, явища, факти як об’єктивні на певному історичному етапі i як такі, що змінюються 3 часом. Отже, вимоги історичного підходу зумовлюють важливість чіткого відображення конкретних педагогічних подій, явищ і фактів на кожному етапі соціально-історичного розвитку [6, с. 24].

На переконання І. Ящук, історичний підхід надає можливість детальніше проаналізувати та краще усвідомити закономірності розвитку конкретного явища, його змісту та напрямів подальшого вдосконалення [14, с. 792].

Використання історичного підходу дозволяє окреслити розвиток громадської діяльності студентської молоді, спираючись на конкретні історичні факти, простежити увесь процес іï розвитку в історичному та сучасному контекстах, виокремити та обгрунтувати етапи розвитку громадської діяльності, iі якісні особливості, що залежали від суспільних потреб певного історичного періоду.

Феноменологія (буквально - вчення феноменів). Виникненням феноменологія забовязана німецькому філософу Е. Гуссерлю (поч. ХХ ст.), який визначав їі як нову філософію. Основою пізнання з погляду феноменології $\epsilon$ вивчення та аналіз особливостей оточуючого світу, повсякденного життя.

I розпочинати вивчення світу, за переконанням Е. Гуссерля, необхідно 3 вивчення свідомості, оскільки саме свідомість надає можливість досліднику сприйняти, осмислити й пізнати реальність.Важливими є не самі факти, події реального світу, а те, як вони сприймаються та осмислюється людиною. Свідомість має вивчатися не як засіб дослідження світу, а як основний предмет філософії.

Подальший розвиток феноменологія отримала у спеціальних дослідженнях спеціалістів різних наукових галузей. Так представники філософської школи (Ф. Брентано, М. Мерло-Понті, М. Хайдеггер та ін.) вважали, що феноменологія є оновленою філософією, в основі якої є положення про свідоме осмислення реалій оточуючого світу. Феноменологія дозволила відмовитись від ірраціоналізму й перейти до рефлексивного дослідження багатоаспектності накопиченого людством досвіду.

3 огляду на дослідження психологів [4, 7], феноменологія розглядається 3 точки зору можливості з’ясувати причини певної поведінки людини, іiі почуття, думки.

Соціологія трактує феноменологічний підхід через пояснення поведінки людей, їх суспільних взаємозв’язків, соціального устрою через з’ясування 
мотивів діяльності людей [10, с. 37].

Цікавим, з нашого погляду, є трактування феноменологічного підходу в контексті педагогічних досліджень. Так, за переконанням О. Сухомлинської, феноменологічний підхід розкриває значення об'єктивного досвіду як основного вимірника сутності людської особистості.

Застосування феноменологічного підходу дає змогу здійснити історичну реконструкцію процесу становлення i розвитку громадської діяльності студентської молоді в закладах вищої освіти України ХХ ст., здійснити об'єктивний аналіз означеного феномена як соціального i психологічного явища.

Аксіологія (від грец. Axios - цінності, logos - слово, поняття) - наука про цінності (духовні, моральні, естетичні тощо), їх природу, взаємозв'язки, чинники, вплив на особистість.

Зазначимо, що аксіологія органічно пов’язана з теорією гуманізму, яка розглядає людину найвищою цінністю суспільства. У зв’язку з цим аксіологія може розглядатися як основа нової філософії освіти із домінантною ідеєю гуманізму.

Аксіологічна складова особистості у світогляді людини спирається на когнітивні й емоційні компоненти, що регулюють потреби і мотивацію. На думку В. Сластьоніна, «ця система включає цінності, що пов’язані 3 затвердженням особистістю своєї ролі в соціальному середовищі та професійній діяльності, цінності, які задовольняють потреби у спілкуванні, цінності, що орієнтують на саморозвиток творчої індивідуальності, цінності, які дозволяють здійснити самореалізацію, задовольнити прагматичні потреби» [9, c. 138].

Використання аксіологічного підходу в контексті нашого дослідження дозволяє визначити пріоритетні цінності особистості, суспільства та їх уплив на характер громадської діяльності студентів досліджуваного періоду, схарактеризувати сутнісно-змістовну значущість об'єкту та корисність предмета дослідження.

Цивілізаційний підхід, який був обгрунтований Г. Корнетовим [5] як урахування не лише особливостей суспільно-історичних формацій, але і всієї суми знань про людину, здобутих у різних галузях знань. Цівілізаційний підхід дозволяє забезпечити цілісність у розумінні вітчизняного історикопедагогічного процесу при аналізі проблеми розвитку студентської громадської діяльності в закладах вищої освіти України.

Парадигмально-педагогічний підхід було започатковано завдяки ідеям Т. Куна [15], який визначив парадигму як систему наукових досягнень, що полягає в розроблених теоріях та обгрунтованих методах, на основі яких зрозуміло, які необхідно використовувати способи діяльності для розгляду наукової проблеми в конкретній галузі знань. Дослідник виокремив три етапи розвитку наукової дисципліни: препарадигмальний (який передує встановленню парадигми), панування парадигми, кризовий (зміна парадигми, перехід від однієї парадигми до іншої). 
Даний підхід також був обгрунтований І. Зайченком, О. Сухомлинською. Парадигмально-педагогічний підхід надає можливість об'єктивного аналізу об'єкта дослідження та озброює відповідними методами для розв'язання поставленої наукової проблеми.

Даний підхід дозволяє розглядати розвиток громадської діяльності студентської молоді в закладах вищої освіти України XX ст. 3 позицій педагогічної науки, а саме: іiі динамічного поступу, становлення різних точок зору на громадську діяльність протягом досліджуваного періоду.

Висновки. 3 огляду на вищесказане, можна стверджувати, що для історико-педагогічного дослідження доцільно орієнтуватися на сукупність науково-методологічних підходів, система яких дозволяє відобразити цілісність досліджуваних процесів і явищ.

Важливими для наукового осмислення проблеми розвитку громадської діяльності студентської молоді в закладах вищої освіти України в XX ст. є такі підходи, як: системний, синергетичний, історіографічний, культурологічний, хронологічний, історичний феноменологічний, аксіологічний, цивілізаційний, парадигмально-педагогічний підходи.

Перспективою подальших розвідок $\epsilon$ вивчення та аналіз термінологічного поля дослідження проблеми розвитку громадської діяльності студентської молоді вищих навчальних закладів України XX ст.

\section{Лimepamypa}

1. Бастун М.В. Культурологічний підхід в освіті та його психологопедагогічне забезпечення. Горизонты образования. 2012. №3 Т.2. С. 170-175.

2. Горбань Ю.А. Історичне дослідження: науково-методичні підходи до написання дисертаційної роботи. Історія науки і біографістика. 2012. №1. С.112. URL: //http:inb.dnsgb.com.ua2012-112_gorban.pdf

3. Гура В.В. Культурологический поход как теоретикометодологическая основа гуманизации информационных технологий обучения : автореф. дис. канд. пед. наук. 13.00.01. Ростов-на-Дону, 1994. 16 с.

4. Козлов Н. Энциклопедия практической психологии. Москва : Эксмо, 2015. $752 \mathrm{c}$.

5. Корнетов Б.Г. Цивилизационный подход к изучению всемирного историко-педагогического процесса. Москва, 1994. 265 с.

6. Кушнір В.М. Профільне навчання в історії розвитку вітчизняної школи (друга половина XIX - XX ст.): монографія. Умань: Видавець «Сочінський», 2016. 418 с.

7. Паркулаб О.Г. Феноменологічний аналіз у віковому екзистенційному консультуванні : автореф. дис. канд. психол. наук. 19.00.01. Івано-Франківськ, 2004. 19 c.

8. Посохов С.І., Куделя С.М., Зайцев Л.Ю. Історіографічний словник: навч. посіб. для студентів історичних факультетів університетів. Харків: Східнорегіональний центр гуманітарноосвітніх ініціатив, 2004. 320 с.

9. Сластенин В.А. Педагогика. М., 1996, 576 с. 
10. Соколов С.В. Феноменологическая социология : учеб. пособие для вузов. Москва, 2010. 176 с.

11. Хакен Г. Синергетика (Synergetics). Москва, 1980. 405 с.

12. Шипилина Л.А. Методология и методы психолого-педагогических исследований: учебное пособие. Москва., 2011. 204 с.

13. Шкабара И.Е. Современные методологические подходы в организации историко-педагогического исследования. Екатеринбург : Образование и наука, 2005. С. 39-43.

14. Ящук I. Виховання майбутніх педагогів у вищому педагогічному навчальному закладі (1920-1991 pp.) як предмет історико-педагогічного дослідження. Педагогічний дискурс. 2013. Вип. 15. С. 792-799.

15. Kuhn T.S. The Structure of Scientific Revolutions. Chicago : University of Chicago Press, 2012. 264 p.

\section{References}

1. Bastun, M. (2012). Kulturolohichnyi pidkhid v osviti ta yoho psykholohopedahohichne zabezpechennia [Culturological approach in education and its psychological and pedagogical support]. Horyzonty obrazovaniia,. 3, 170-175.

2. Horban, Yu. (2012). Istorychne doslidzhennia: naukovo-metodychni pidkhody do napysannia dysertatsiinoi roboty [Historical research: scientific and methodological approaches to writing a dissertation]. Istoriia nauky i biohrafistyka, 1, $1-12$.

3. Hura, V.V. (1994). Kulturolohycheskyi pokhod kak teoretykometodolohycheskaia osnova humanyzatsyy informatsyonnukh tekhnolohyi obuchenyia [Culturological approach as a theoretical and methodological basis for the humanization of information technologies of education] (Abstract of candidate's thesis). Rostov-on-Don.

4. Kozlov, N. (2015). Entsyklopedyia praktycheskoi psykholohyy [Encyclopedia of practical psychology]. Moscow : Eksmo.

5. Kornetov, B. (1994). Tsivilizatsionnyiy podhod $k$ izucheniyu vsemirnogo istoriko-pedagogicheskogo protsessa [Civilizational approach to the study of the world historical and pedagogical process]. Moscow.

6. Kushnir, V. (2016). Profilne navchannia $v$ istorii rozvytku vitchyznianoi shkoly (druha polovyna XIX - XX st.) [Profile training in the history of development of domestic school development (second half of the $19^{\text {th }}-20^{\text {th }}$ centuries)]. Uman: Vydavets «Sochinskyi».

7. Parkulab, O.H. (2004). Fenomenolohichnyi analiz $u$ vikovomu ekzystentsiinomu konsultuvanni [Phenomenological analysis in age-related existential counseling] (Abstract of candidate's thesis). Ivano-Frankivsk.

8. Posokhov, S., Kudelia, S. \& Zaitsev, L. (2004). Istoriohrafichnyi slovnyk [Historiographical dictionary]. Kharkiv: Skhidnorehionalnyi tsentr humanitarnoosvitnikh initsiatyv.

9. Slastenyn, V. (1996). Pedahohika [Pedagogy]. Moscow. 
10. Sokolov, S. (2010).

Fenomenolohycheskaia

sotsyolohyia

[Phenomenological Sociology]. Moscow.

11. Khaken, H. (1980). Sinerhetika [Synergetics]. Moscow.

12. Shypylyna, L. (2011). Metodologiya i metodyi psihologo-pedagogicheskih issledovaniy [Methodology and methods of psychological and pedagogical research]. Moscow.

13. Shkabara, Y. (2005). Sovremennyie metodologicheskie podhodyi v organizatsii istoriko-pedagogicheskogo issledovaniya [Modern methodological approaches in the organization of historical and pedagogical research]. Ekaterinburg : Obrazovanie i nauka.

14. Yashchuk, I. (2013). Vykhovannia maibutnikh pedahohiv u vyshchomu pedahohichnomu navchalnomu zakladi (1920-1991 rr.) yak predmet istorykopedahohichnoho doslidzhennia [Education of future teachers in higher pedagogical educational institution (1920-1991) as a subject of historical and pedagogical research]. Pedahohichnyi dyskurs, 15, 792-799.

15. Kuhn, T. (2012). The Structure of Scientific Revolutions. Chicago: University of Chicago Press. 